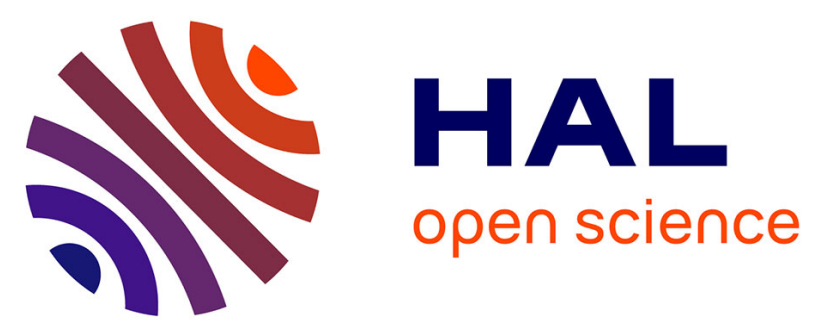

\title{
EVALUATION OF TYPE-SPECIFIC HPV PERSISTENCE AND HIGH-RISK HPV VIRAL LOAD QUANTITATION IN HPV POSITIVE WOMEN UNDER 30 WITH NORMAL CERVICAL CYTOLOGY
}

Xavier Carcopino, Noel Bolger, Mireille Henry, Julien Mancini, Leon Boubli, Daniel Olive, Sinead Cleary, Walter Prendiville, Catherine Tamalet

\section{To cite this version:}

Xavier Carcopino, Noel Bolger, Mireille Henry, Julien Mancini, Leon Boubli, et al.. EVALUATION OF TYPE-SPECIFIC HPV PERSISTENCE AND HIGH-RISK HPV VIRAL LOAD QUANTITATION IN HPV POSITIVE WOMEN UNDER 30 WITH NORMAL CERVICAL CYTOLOGY. Journal of Medical Virology, 2011, 83 (4), pp.637. 10.1002/jmv.22022 . hal-00614696

\author{
HAL Id: hal-00614696 \\ https://hal.science/hal-00614696
}

Submitted on 15 Aug 2011

HAL is a multi-disciplinary open access archive for the deposit and dissemination of scientific research documents, whether they are published or not. The documents may come from teaching and research institutions in France or abroad, or from public or private research centers.
L'archive ouverte pluridisciplinaire HAL, est destinée au dépôt et à la diffusion de documents scientifiques de niveau recherche, publiés ou non, émanant des établissements d'enseignement et de recherche français ou étrangers, des laboratoires publics ou privés. 


\section{EVALUATION OF TYPE-SPECIFIC HPV PERSISTENCE AND HIGH-RISK HPV VIRAL LOAD QUANTITATION IN HPV POSITIVE WOMEN UNDER 30 WITH NORMAL CERVICAL CYTOLOGY}

\begin{tabular}{|r|l|}
\hline Journal: & Journal of Medical Virology \\
\hline Manuscript ID: & JMV-10-2143.R1 \\
\hline Diley - Manuscript type: & Research Article \\
\hline Date Submitted by the & 11 -Nov-2010 \\
\hline Complete List of Authors: & $\begin{array}{l}\text { carcopino, xavier; hopital nord, obstetrics and gynaecology } \\
\text { bolger, noel } \\
\text { Henry, Mireille } \\
\text { mancini, julien } \\
\text { boubli, leon } \\
\text { olive, daniel } \\
\text { cleary, sinead } \\
\text { prendiville, walter } \\
\text { Tamalet, Catherine }\end{array}$ \\
\hline Keywords: & $\begin{array}{l}\text { Human Papillomavirus, Cervical cancer, viral load, genotyping, } \\
\text { screening }\end{array}$ \\
\hline
\end{tabular}

\section{SCHOLARONE ${ }^{\text {M }}$ \\ Manuscripts}




\begin{tabular}{lcc}
\hline & \multicolumn{2}{c}{ HPV test } \\
\cline { 2 - 3 } & $\begin{array}{c}\text { Initial } \\
(\mathbf{n = 1 9 9})\end{array}$ & $\begin{array}{c}\text { 1-year follow up } \\
(\mathbf{n = 3 9})\end{array}$ \\
\hline Number of HPV types detected n (\%) & $11(20.6)$ & $17(43.6)$ \\
1 & $16(8)$ & $8(20.5)$ \\
$\geq 2$ & $22(11.1)$ & $15(38.5)$ \\
HPV types detected n (\%) & $11(5.5)$ & $8(20.5)$ \\
HPV16 & $6(3)$ & $2(5.1)$ \\
HPV18 & $8(4)$ & $0(0)$ \\
HPV31 & $5(2.5)$ & $1(2.6)$ \\
HPV33 & $25(12.6)$ & $7(17.9)$ \\
Other HR-HPV types* & & \\
LR-HPV types** & $8.5 .10^{5}\left(2.04 .10^{6}\right)$ & $5.27 .10^{5}\left(1.08 .10^{6}\right)$ \\
HPV viral load (n copies / 10 cells) mean (SD) & \\
HPV16 & $9.4 .10^{5}\left(2.87 .10^{6}\right)$ & $3.66 .10^{5}\left(9.24 .10^{5}\right)$ \\
HPV18 & $4.57 .10^{6}\left(4.65 .10^{6}\right)$ & $2.11 .10^{8}\left(2.88 .10^{8}\right)$ \\
HPV31 & $2.37 .10^{6}\left(3.85 .10^{6}\right)$ & - \\
HPV33 & & \\
\hline
\end{tabular}

Table 1. Results of initial and 1-year follow up HPV testing and typing.

HR-HPV: high-risk HPV; LR-HPV: low-risk HPV.

*Other high-risk HPV types initially detected: 4(2\%) HPV58 and 1(0.5\%) HPV82.

**Low-risk HPV types initially detected - 25 patients were infected by 30 LR-HPV types (because of multiple infections): 8(4\%) HPV6, 6(3\%) HPV53, 4(2\%) HPV66, 2(1\%) HPV61, 2(1\%) HPV62, 2(1\%) HPV 83, 1(0.5\%) HPV1, 1(0.5\%) HPV11, 1(0.5\%) HPV54, 1(0.5\%) HPV70, 1(0.5\%) HPV81 and 1(0.5\%) HPV84. 


\begin{tabular}{|c|c|c|c|c|c|c|}
\hline \multirow{3}{*}{$\begin{array}{c}\text { HPV type initially } \\
\text { detected }\end{array}$} & \multirow{3}{*}{$\begin{array}{l}\text { Number of } \\
\text { patients } \\
\text { followed-up }\end{array}$} & \multirow{3}{*}{$\begin{array}{l}\text { 1-year specific } \\
\text { persistent HPV } \\
\text { infection rate } \\
(\%)[95 \% \mathrm{CI}]\end{array}$} & \multicolumn{4}{|c|}{ Cervical intraepithelial neoplasia } \\
\hline & & & \multicolumn{2}{|c|}{ All grades } & \multicolumn{2}{|c|}{ Grade 2 or 3} \\
\hline & & & $\begin{array}{l}\text { Incidence rate } \\
(\%)[95 \% \mathrm{CI}]\end{array}$ & $\begin{array}{l}\text { Women with 1-year } \\
\text { specific persistent HPV } \\
\text { infection n }(\%)\end{array}$ & $\begin{array}{l}\text { Incidence rate } \\
(\%)[95 \% \mathrm{CI}]\end{array}$ & $\begin{array}{c}\text { Women with 1-year } \\
\text { specific persistent HPV } \\
\text { infection n }(\%)\end{array}$ \\
\hline HPV16 & 12 & $92[62-100]$ & $33[10-65] \dagger$ & $3(75)$ & $8[0-39]$ & $1(100)$ \\
\hline HPV 18 & 7 & $57[18-90]$ & $14[0-58]$ & $0(0)$ & 0 & - \\
\hline HPV31 & 5 & $20[1-72]$ & 0 & - & 0 & - \\
\hline HPV33 & 3 & 0 & 0 & - & 0 & - \\
\hline Other HR-HPV types* & 4 & $25[1-81]$ & 0 & - & 0 & - \\
\hline LR-HPV types** & 20 & $15[3-38]$ & $5[1-25] \div$ & $0(0)$ & 0 & - \\
\hline
\end{tabular}

Table 2. Rate of one-year HPV type persistence and cervical intraepithelial neoplasia incidence.

HR-HPV: high-risk HPV; LR-HPV: low-risk HPV.

* Other high risk HPV types: 3 HPV58 and 1 HPV82.

** Low risk HPV types: 6 HPV53, 4 HPV6, 2 HPV62, 2 HPV66, 2 HPV83, 1 HPV11, 1 HPV61, 1 HPV 81 and 1 HPV84.

$\uparrow 3$ patients were diagnosed with grade 1 Cervical intraepithelial neoplasia and one with grade 2 cervical intraepithelial neoplasia.

$\$ 1$ patient was diagnosed with grade 1 cervical intraepithelial neoplasia.

Bold style indicates statistical significance when comparing with other HPV types. 
Women $\leq 30$ years

No previous history of cervical lesion / abnormal cytology $(n=372)$

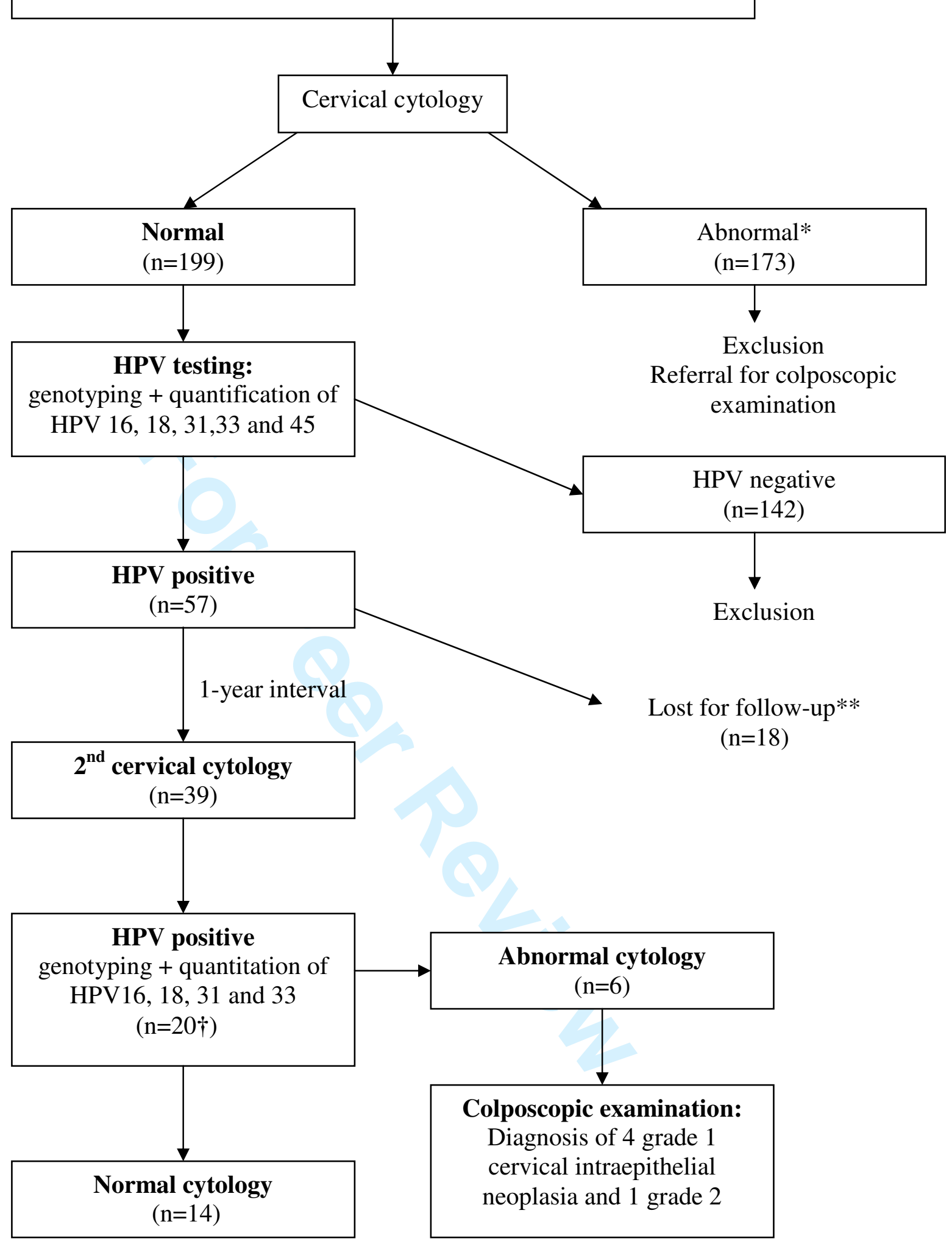


Figure 1. Study design

* Smear was considered abnormal if borderline nuclear abnormalities (BNA) or more severe abnormalities were identified.

** 1 patient got pregnant and thus did not attend to the $2^{\text {nd }}$ cervical smear.

$\dagger 20$ cases of type-specific HPV persistent infection were identified: 11 HPV16, 4 HPV 18, 1 HPV 31, 0 HPV 33, 3 LR-HPV, and 1 HR-HPV different from types 16, 18, 31 and 33. 


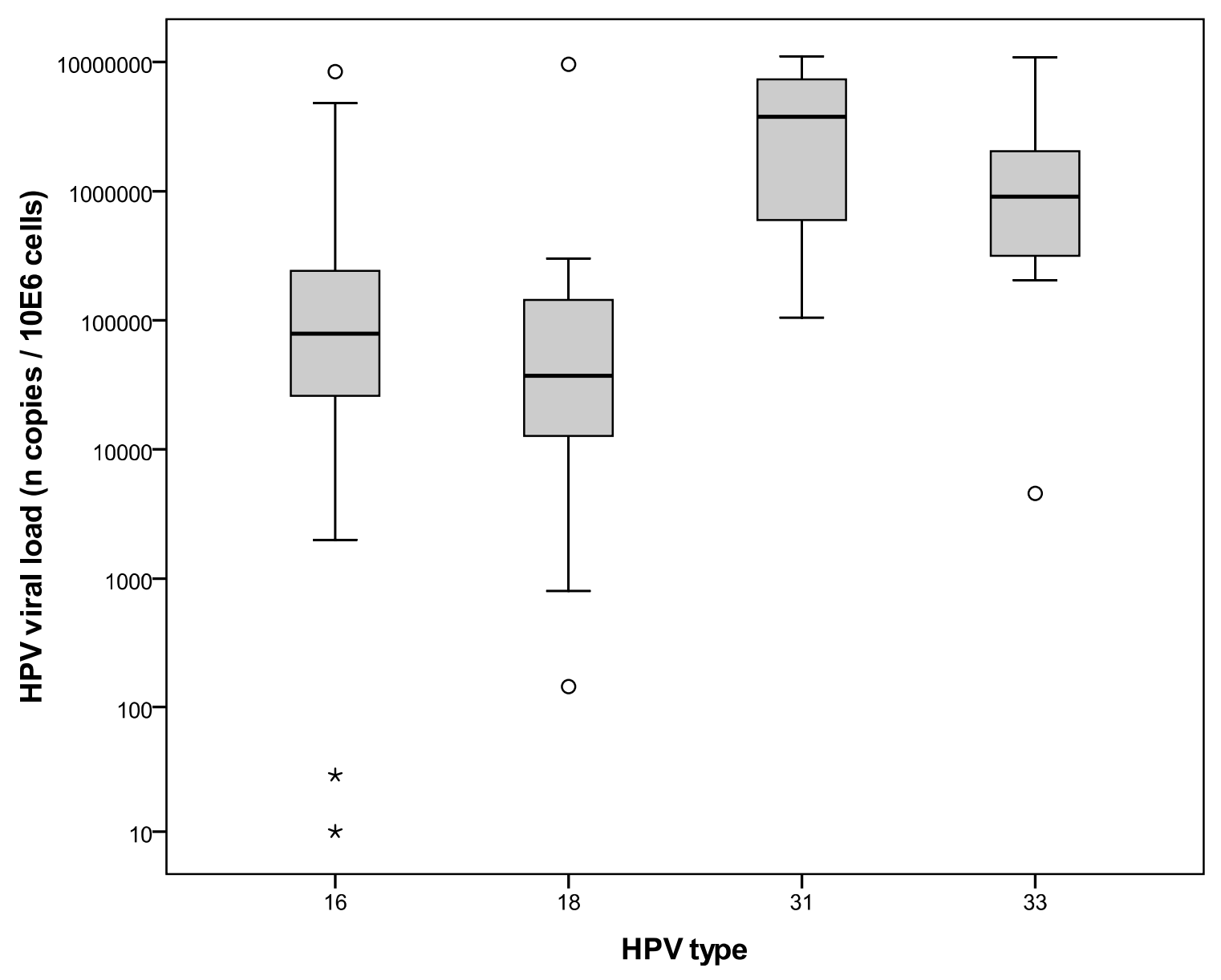

Figure 2. Distribution of HPV16, 18, 31 and 33 viral load in women under 30 with normal smear at the time of inclusion (logarithmic scale). HPV31 viral load was statistically higher than HPV16 $(\mathrm{p}=0.015)$ and HPV18 viral load $(\mathrm{p}=0.019)$. 


\section{Institutions:} Ireland.

\section{EVALUATION OF TYPE-SPECIFIC HPV PERSISTENCE AND HIGH-RISK HPV} VIRAL LOAD QUANTITATION IN HPV POSITIVE WOMEN UNDER 30 WITH NORMAL CERVICAL CYTOLOGY

Authors: Xavier Carcopino (1, 2, 3)*, Noel Bolger (4), Mireille Henry (5), Julien Mancini

(6), Léon Boubli (1), Daniel Olive (3), Sinead Cleary (7), Walter Prendiville (7), Catherine

1. Department of Obstetrics and Gynaecology, Hôpital Nord, Chemin des Bourrely, 13915 cedex 20, Marseille, France.

2. University of Medicine of Marseille, Bd Jean Moulin, 13005 Marseille, France.

3. Laboratory of Tumor Immunology, Institut Paoli Calmettes, 232 Bd Ste Margueritte, 13009 Marseille, France.

4. Pathology Department, The Coombe Women and Infants University Hospital. Dublin 8.

5. Department of Bacteriology and Virology, Centre Hospitalo-Universitaire Timone, 264 Rue St Pierre, 13385 Marseille Cedex 05, France

6. Department of Public Health and Epidemiology, Hôpital de la Timone, 264, Rue SaintPierre 13385 Marseille Cedex 5, France

7. Department of Obstetrics and Gynaecology, Royal College of Surgeons in Ireland, The Coombe Women and Infants University Hospital, Dublin 8, Ireland.

\section{*Corresponding author's contact details:}

Xavier CARCOPINO, MD 
1 Department of Obstetrics and Gynaecology

2 Hôpital Nord

3 Chemin des Bourrely, 13915 Cedex 20, Marseille, France

4 Telephone (day and evening): (33) 491964853

5 E-mail: $\underline{x c a r c o @ f r e e . f r}$

6

7 Shortened title: HPV type and viral load in young women with normal smear 8 
Carcopino et al.

\section{ABSTRACT}

2

3 The persistence of high-risk HPV (HR-HPV) infection is necessary for the development of

4 cervical intraepithelial neoplasia. The aim of this study was to evaluate if HR-HPV typing

5 and HPV16, 18, 31 and 33 quantitation are predictive for type-specific infection persistence

6 and/or the development of CIN in women under 30 with normal cervical cytology. Young

7 women (under 30) attending a family planning clinic who were HPV positive with normal

8 cervical cytology were included. HPV genotyping was assessed by MY09/ MY11 PCR,

9 sequencing, phylogenetic analysis, and cloning when necessary. HR-HPV viral load was

248 words quantified using duplex real-time PCR. Study patients were offered for a second smear and HR-HPV detection and quantitation after twelve months. HR-HPV was identified in 43 (21.9\%) of the 199 included women. Of these, 39 patients had a second cervical sample taken within a mean interval of 11.7 months (8.8-18.3 months). The mean HR-HPV 16, 18, 31 and 33 initial viral load was $1.9 \times 10^{6}$ copies per millions cells. The level of viral load did not reveal any significant association with type-specific HR-HPV persistence or the subsequent development of cervical intraepithelial neoplasia. Only HPV16 infection was significantly more likely to persist (91.7\% vs. $33.1 \%, \mathrm{p}=0.001)$ and to develop CIN (33.3\% vs. $3.7 \%$, $\mathrm{p}=0.025$ ). In women under 30 with normal cytology, HR-HPV viral load is common and is not predictive of HPV persistence or the development of cervical intraepithelial neoplasia. HPV16 positive women are significantly more likely to have persistent infection and to develop cervical intraepithelial neoplasia.

Key words: Human Papillomavirus, cervical cancer, viral load, genotyping, screening. 


\section{INTRODUCTION}

2

3 High-risk or oncogenic, human papillomavirus (HR-HPV) infection is the major risk factor

4 for the development of cervical cancer and cervical intraepithelial neoplasia. In France, 97\%

5 of cervical cancers are HPV positive [Pretet et al., 2007]. Among HR-HPV types, HPV16, is

6 by far the most prevalent type and is identified in $73 \%$ of cervical cancers, followed by HPV

$718(19 \%), 31(7 \%)$ and $33(4 \%)$ [Pretet et al., 2007]. For this reason HPV testing has been

8 considered as an alternative method of cervical pre-cancer screening. Compared to cervical

9 cytology, HPV testing is more sensitive but less specific in the detection of grade 2 or more cervical intraepithelial neoplasia [Arbyn et al., 2006; Cuzick et al., 2006; Koliopoulos et al., 2007]. The Superiority of HPV testing over cytology or visual inspection techniques has also been demonstrated in low resource setting countries [Sankaranarayanan et al., 2009]. In this study screening with HPV and subsequent management of screen positive women has been shown to result clinically important and statistically significant reduction in the number of advanced stages cervical cancers and of overall cervical cancer related mortality

Age has a major impact on the clinical utility of HPV testing being very much more specific in women over 30 years [Koliopoulos et al., 2007; Mayrand et al., 2007]. HPV infection is extremely common in young women and in the great majority of cases it is both transient and ultimately harmless. Following initial exposure to HR-HPV, the great majority of women will clear their infection in 8 to 10 months without the development of a cervical lesion [Dalstein et al., 2003; Ho et al., 1998; Woodman et al., 2001]. Thus, persistence of HPV infection only affects a small minority of women [Bosch and Munoz, 2002; Franco et al., 1999; Ho et al., 1998]. More than HR-HPV infection itself, it is the persistence of the same HR-HPV infection that has been demonstrated to be the most important risk factor for cervical intraepithelial neoplasia [Dalstein et al., 2003; Nobbenhuis et al., 1999; Schlecht et al., 2001]. 
1 Thus, the positive predictive value of a single HPV test in young women is poor and only a

2 minority of these women will develop a cervical lesion [Cuzick et al., 2003]. Factors that

3 influence HR-HPV persistence remain unknown and predictive factors for HR-HPV infection

4 persistence would be clinically valuable.

5 With the increased use of HPV testing in routine practice, physicians must consider how to 6 manage HPV positive young women who have normal cytology. This presents a clinical 7 dilemma and may easily result in unnecessary treatment with the potential for subsequent 8 pregnancy related morbidity and perinatal mortality [Arbyn et al., 2008; Kyrgiou et al., 2006].

9 Determination of HR-HPV viral load would be useful if it could predict HR-HPV persistence and Cervical Intraepithelial Neoplasia [Bae et al., 2009; Dalstein et al., 2003; Lai et al., 2008; Munoz et al., 2009; van Duin et al., 2002]. The predictive value of HR-HPV detection could be HPV type-dependant with perhaps a higher risk for women with high HPV 16 viral load [Gravitt et al., 2007; Moberg et al., 2004; Moberg et al., 2005].

The aim of this study was to evaluate HPV type-specific prevalence and persistence in a population of women under 30 with normal cervical cytology. In that specific population, HPV 16, 18, 31 and 33 viral load, referred to as "oncogenic" HPV viral load, was evaluated as a predictive factor of type-specific HPV infection persistence and of colposcopically documented cervical intraepithelial neoplasia. The impact of HPV genotyping was also evaluated.

\section{MATERIALS AND METHODS}

\section{Patients and design of the study}

4 The study design is summarized in Figure 1 . All women under 30 with no previous history of cervical lesion or of abnormal cervical cytology attending an Irish Family Planning 
1 Association (IFPA) clinic in Tallaght, (Dublin, Ireland) for routine screening cervical

2 cytology were invited to participate to the study. All had a liquid-based cervical cytology

3 performed using the ThinPrep® pap test (Hologic Inc, Nasdaq: Holx) and dedicated cervical

4 brush. Women with abnormal cervical cytology were referred for colposcopic examination or

5 repeat cervical cytology according to British Society of Colposcopy and Cervical Pathology

6 (BSCCP) guidelines and were then excluded form the study. All women with normal cervical

7 cytology had a HPV test performed directly on the remaining suspension of the ThinPrep®

8 pap test vial. HPV negative women were excluded from the study and referred for routine

9 screening cytology i.e. three yearly. HPV positive women were asked to return in one-year for a repeat cervical cytology and HPV test. Subsequent cervical smears were performed at the 11 Colposcopy Clinic of the Coombe Women and Infants University Hospital. All were tested 12 for HPV with systematic genotyping of HPV positive sample and quantitation of HPV 16, 18, $13 \quad 31$ and 33 viral load. Women with a second abnormal smear were referred for colposcopic 14 examination. Colposcopic examinations were blinded to the results of HPV genotyping and 15 viral load quantitation.

16 Study protocol received approval from Ethics Committees of both the Coombe Women and 17 Infants University Hospital and the Adelaïde and Meath Hospital in Tallaght, Dublin. 18 Informed consent was obtained from all the women participating to the study.

\section{Cervical cytology analysis}

21 All cervical smears were analyzed at the Pathology department of the Coombe Women and 22 Infants University Hospital (Dublin, Ireland). Analysis were performed using ThinPrep® 23 Imaging system (Hologic Inc, Nasdaq: Holx). All slides were first screened using the Review 24 Scopes ${ }^{\circledR}$ followed by manual secondary screening. Negative cases were signed out by the 25 cytotechnologists and all abnormal cases (Borderline Nuclear Abnormality or greater) were 
1 signed out by the consultant Pathologist. Cervical cytology analysis were blinded to the result

2 of HPV genotyping and viral load quantitation.

3

$4 \quad$ Virological analysis

5 HPV testing was performed at the department of Virology of the Timone's Hospital 6 (Marseilles, France). All HPV tests were performed using the remaining fluid in the liquid 7 based cytology vials. HPV genotyping was assessed by PCR (MY09/ MY11 primers), 8 sequencing, phylogenetic analysis and cloning if necessary, as described previously [Tamalet 9 et al., 2010]. Quantitation of HPV 16, 18, 31 and 33 positive samples were performed using quantitative duplex real-time PCR method, as reported previously [Carcopino et al., 2006]. 11 HPV viral load was expressed as the number of HPV copies per million cells.

12 For quantification, we used a plasmid which contained the five target sequences of interest: 13 HPV 16,HPV 31, HPV 33,HPV 45 (each on E6 gene), HPV 18 (on E7 gene), and human 14 albumin gene (on exon12). This method allowed HPV 16 and 18, 31, 33, and 45 and albumin gene copy number to be quantified in the same assay. So, HPV viral load could be expressed 16 as HPV copies per cell or per million cells. For the purpose of intra-assay reproducibility, the 17 standard curve was tested 10 times on the same plate and serial dilutions of positive samples 18 (from 107 copies to 1 copy per assay) each with a high HPV 16, 18, 31, 33, or 45 value were 19 tested in duplicate to establish the sensitivity and the reproducibility of the method. We 20 obtained a lower detection limit of 5 copies per $5 \mu$ l of sample as well for HPV 16,18, 31, 33, 2145 as for albumin. The linearity was excellent from the highest value to 1 copy per $5 \mu l$ of 22 sample. The data revealed an excellent reproducibilirty of the assays as well for high, median 23 or low values. The coefficient of correlation varied from $98.9 \%$ for HPV 18 to $99.7 \%$ for 24 HPV 16. For the purpose of inter-assay reproducibility, the coefficient of variation (CV) was 
1 determined for each reaction. Mean CV for each point of the quantification curve in HPV 16,

$218,31,33,45$ and albumin was $<3 \%$.

3

\section{$4 \quad$ Statistical analysis}

5 Statistical analysis was performed using SPSS 15.0 software for Windows (SPSS Inc,

6 Chicago, Illinois). Groups were compared using the Chi square test or the Fisher exact test for

7 qualitative characteristics, and using the Mann-Whitney test for continuous ones. A two-sided

$8 \quad \mathrm{P}$ value of less than 0.05 was considered statistically significant.

12 Recruitment ran from September 2007 to the end of March 2009, during which 372 patients 13 participated in the study. Of these, 199 had normal cytology. 173 had an abnormal cervical 14 smear, were excluded from the study and were referred for colposcopic examination or repeat

\section{RESULTS}

cervical cytology. All of the 199 patients whose cervical cytology was normal were tested for HPV. The overall HPV prevalence was $28.6 \%$ (57/199) (Table 1). HR-HPV was identified in $43(21.6 \%)$ patients. The most prevalent HPV genotypes were HPV $16(11.1 \%)$ and HPV 18 (5.5\%) followed by HPV 33 (4\%), HPV 6 (4\%), HPV 31 (3\%), HPV 53, 58, 66, 61, 62 and 83 (3-1\%). Single HPV infection was observed in 41 (20.6\%) while $16(8 \%)$ patients had at least two different HPV types. The mean HR-HPV viral load for HPV 16, 18, 31 and 33 was $1.5 \times 10^{6}$ copies / million cells (Standard Deviation (SD): $3.05 \times 10^{6}$ ). The mean HPV 31 viral load was statistically higher than the mean HPV $16(\mathrm{p}=0.015)$ or HPV 18 viral loads $(\mathrm{p}=0.019)$ (Figure 2).

After the exclusion of all HPV negative women, 57 remained for analysis. Of these, 39 (68.4\%) patients had a second cervical sample taken within a mean interval of 11.7 months 
1 (min-max: 8.8-18.3 months). One patient conceived and declined a second cervical sample.

2 Seventeen patients were lost to follow up despite several reminder invitations by mail and

3 telephone (Figure 1). The mean patient age was 24.8 years (min-max: 18-30 years). The

4 mean interval between smears was comparable for HPV 16, 18, 31 and 33 positive patients as

$5 \quad$ well as for patients who were positive for other HPV types.

6 All of the 39 patients were tested for HPV. Type-specific persistent HPV infection was

7 identified in $20(51.3 \%)$. The mean age of patients with persistent infection and of those who 8 cleared their infection was comparable: 24.7 years vs. 24.5, respectively. HPV 16 was 9 significantly more likely to persist than were all other types: $11(91.7 \%)$ vs. 9 (33.3\%), 10 respectively $(\mathrm{p}<0.001)$.

11 Compared to HR-HPV types, low-risk HPV (LR-HPV) were significantly less likely to 12 persist: $17(54.8 \%)$ vs. $3(15.0 \%)$, respectively ( $\mathrm{p}=0.004)$ (Table 2). In HPV 16, 18, 31 and 1333 positive patients the initial overall viral load was not predictive of type specific HPV 14 infection. Mean initial HPV viral load of women with persistent HPV 16, 18, 31 or 33 15 infection was $1.2 \times 10^{6}$ copies per million cells whereas viral load of women who had cleared 16 their infection was $5.3 \times 10^{6}$ copies per million cells $(\mathrm{p}=0.173)$.

17 The result of a second smear test was abnormal in 6 of the 39 patients. Three women were 18 reported as having borderline nuclear abnormality (BNA), 2 low-grade squamous 19 intraepithelial lesion (LSIL) and 1 high-grade squamous intraepithelial lesion (HSIL). After 20 colposcopic examination, one patient was diagnosed with normal cervix. Grade 1 cervical 21 intraepithelial neoplasia was diagnosed in 4 patients who were advised to have a follow up 22 colposcopy and smear within a year. One patient was diagnosed with grade 2 cervical 23 intraepithelial neoplasia, confirmed at LLETZ (large loop excision of the transformation 24 zone). 
1 Patients diagnosed with cervical intraepithelial neoplasia (any grade) were not significantly

2 more likely to have persistent HPV infection: 3 (60\%) vs. 17 (50\%), respectively, though

3 these numbers do not allow accurate assessment of risk. Nor was the initial HPV 16, 18, 31

4 or 33 viral load predictive of cervical intraepithelial neoplasia. Initial mean HPV viral load in

5 patients who were diagnosed with cervical intraepithelial neoplasia was $5.2 \times 10^{4}$ copies per 6 million cells compared to $2.9 \times 10^{6}$ copies per million cells in women with a normal cervix $7 \quad(\mathrm{p}=0.263)$. Also the mean age was comparable in both groups: 23.7 years vs. 24.7 years 8 ( $=0.515)$. Finally, compared to other HPV types, only HPV 16 infection was significantly 9 associated with a higher probability of developing cervical intraepithelial neoplasia: 1 (3.7\%)

\section{DISCUSSION} confirms that HPV, and particularly HR-HPV infection, is very common in women under 30 years old with normal cervical cytology. Such finding concurs with the results of other studies. In women who reported recent coitarche and who reported just one sexual partner, the 21 1-year cumulative incidence rate of HPV infection is $28.5 \%$ (IC à $95 \%: 20,6-38,6 \%$ ) and 22 reaches almost 50\% after 3 years [Winer et al., 2008]. The overall cumulative incidence rate 23 of HPV infection in 25 year old women has been estimated to be $80 \%$ [Winer et al., 2006]. 24 Thus, the prevalence of HPV infection in young women is very high, with a peak of 25 prevalence of $19.6 \%$ for women between 25 and 29 years. This appears to decline to $4.3 \%$ in 
1 women over 30 [Jacobs et al., 2000]. Although the rates for HR-HPV are generally lower, the

2 prevalence and natural history is comparable to overall HPV. The best evidence suggests that

3 in 20-24 and 25-29 years old women, HR-HPV prevalence is $13 \%$ and $17 \%$ respectively and

4 will decrease to 2.5 and $3.9 \%$ in women over 30 [Cibas et al., 2007; Jacobs et al., 2000].

5 Interestingly, despite the limited number of 39 women in the key core study group, it should

6 be noted that 20 women $(51.3 \%)$ presented persistent HR-HPV infection. Of these 20 women,

7 six had abnormal cytology, while 14 had sustained normal cytology after a mean interval time

8 period of 11.7 months. Thus, since the critical point is actually to know the future of this

9 persistent HPV infection in these 14 young women it will be of highest importance to monitor

10 their cytological and virological follow up. What is more, given the consistent association

11 between persistent infection and increased risk of cervical precancer and cancer, persistent

12 HPV infection was the virological endpoint proposed as a relevant clinical marker in the

13 Cervarix vaccine trial [Paavonen et al., 2009](Paavonen, Lancet 2009, 374:301-14). Finally

14 the high incidence of transient HPV infection in young women could also explain the higher

15 probability of abnormal smear in young women as the cytopathic effects of HPV can be 16 detected on cytology [ACOG, 2009]. However, explanation for higher probability of 17 abnormal cytology, as observed in the present study, is probably multifactorial and includes 18 the low socioeconomic level of women attending to the IFPA clinic in Tallaght [Cotton et al., 19 2007].

20 In the present study the initial HPV 16, 18, 31 and 33 viral load was not found to be 21 predictive of type-specific HPV persistence or the development of cervical intraepithelial 22 neoplasia although in other studies HPV viral load has been demonstrated to be correlated 23 with HPV persistence and subsequent cervical pre-malignancy [Bae et al., 2009; Dalstein et 24 al., 2003; Lai et al., 2008; Munoz et al., 2009; van Duin et al., 2002]. This correlation may 25 vary with HPV type and to be most reliable for HPV 16 [Gravitt et al., 2007; Moberg et al., 
1 2004; Moberg et al., 2005]. It seems that no previous reports have evaluated such a

2 correlation in young women with normal smears.

3 Interestingly, mean HR-HPV viral load was relatively high. Indeed, the mean initial HR-HPV

4 viral load measured in the present study was close to the HPV 16 viral load cut-off $\left(>2.2 \times 10^{7}\right.$

5 copies/million cells) identified by Saunier et al. to allow the identification of women with

6 prevalent grade 2 or 3 cervical intraepithelial neoplasia with a high specificity [Saunier et al.,

7 2008]. Thus, regardless of age, it has been shown that HR-HPV viral load increases

8 significantly with the severity of cervical lesions [Saunier et al., 2008]. But, in a previous

9 study, such significant association was only found in patients over 30 while mean HPV 16

and 18 viral load was already particularly high in women under 30 [Carcopino et al., 2006].

These results suggest that HR-HPV viral load is commonly high in young women, possibly related to the recent occurrence of HPV infection, and would therefore not be of any clinical significance.

In this study, only HPV 16 was found to persist and associated with an increased risk of cervical intraepithelial neoplasia. In comparison, LR-HPV types were significantly less likely to persist. This finding illustrates the high oncogenicity of HPV 16 and points to the potential benefit of HPV genotyping in clinical practice. Indeed, HPV 16 has been already shown to persist over a 8-16 months period [Ralston Howe et al., 2009]. The usefulness of HPV 16 testing in the management of HPV positive women with normal cervical cytology has been already demonstrated [Khan et al., 2005]. In their study the detection of HPV 16 was associated with a $17.2 \%$ risk of grade 3 or more cervical intraepithelial neoplasia over a 10 years period ( $95 \%$ CI: 11,5-22,9). In the present study, the absence of significant association between HPV 16 infection and grade 2 or more cervical intraepithelial neoplasia occurrence may be explained by the small number of HPV positive patients and because the study was limited to one-year's follow-up. 
1 The Management of HPV positive young women with normal cytology remains a clinical

2 challenge. The balance between not overtreating women with a minimal risk of progression

3 to cancer and the risk of treatment related morbidity is a fine line [Arbyn et al., 2008; Kyrgiou

4 et al., 2006]. These results suggest that the use of HPV genotyping and particularly HPV 16

5 identification may be valuable. Because of the risk of HPV 16 persistence and the

6 development of cervical intraepithelial neoplasia, young HPV 16 positive patients with

7 normal smear should be monitored carefully.

8

\section{CONCLUSION}

11 This study extends the understanding of the natural history of HPV in women under 30 with 12 normal cervical cytology. In this specific population, HPV type 16, 18, 31 and 33 viral load is 13 often relatively high. It does not appear to predict type-specific HPV infection persistence or 14 the development of cervical intraepithelial neoplasia. However, in the present study, HPV 16 infection was more likely to persist and HPV 16 positive patients were also more likely to 16 develop cervical intraepithelial neoplasia. The use of HPV typing may be valuable in women 17 under 30.

3020 words

21 FINANCIAL SUPPORT

23 This study was supported by a grant from the "Fondation de France".

\section{ACKNOWLEDGMENTS}


2 We are particularly grateful to the Tallaght's Irish Family Planning Association (IFPA) and 3 particularly to Annet Smith for their great participation to this study. We also want to thank 4 all the patients who accepted to be part of this study. Finally, we thank Fidelma Kavanagh 5 and all the staff of the colposcopy clinic of the Coombe Women's Hospital for their help on 6 the management of patients and samples. 7 


\section{REFERENCES}

2

2009. ACOG Committee Opinion No. 436: evaluation and management of abnormal cervical cytology and histology in adolescents. Obstetrics and gynecology 113:1422-1425.

Arbyn M, Kyrgiou M, Simoens C, Raifu AO, Koliopoulos G, Martin-Hirsch P, Prendiville W, Paraskevaidis E. 2008. Perinatal mortality and other severe adverse pregnancy outcomes associated with treatment of cervical intraepithelial neoplasia: metaanalysis. BMJ 337:a1284.

Arbyn M, Sasieni P, Meijer CJ, Clavel C, Koliopoulos G, Dillner J. 2006. Chapter 9: Clinical applications of HPV testing: A summary of meta-analyses. Vaccine 24:S78-89.

Bae J, Seo SS, Park YS, Dong SM, Kang S, Myung SK, Park SY. 2009. Natural history of persistent high-risk human papillomavirus infections in Korean women. Gynecologic oncology 115:75-80.

Bosch FX, Munoz N. 2002. The viral etiology of cervical cancer. Virus research 89:183-190.

Carcopino X, Henry M, Benmoura D, Fallabregues AS, Richet H, Boubli L, Tamalet C. 2006. Determination of HPV type 16 and 18 viral load in cervical smears of women referred to colposcopy. Journal of medical virology 78:1131-1140.

Cibas ES, Hong X, Crum CP, Feldman S. 2007. Age-specific detection of high risk HPV DNA in cytologically normal, computer-imaged ThinPrep Pap samples. Gynecologic oncology 104:702-706.

Cotton SC, Sharp L, Seth R, Masson LF, Little J, Cruickshank ME, Neal K, Waugh N. 2007. Lifestyle and socio-demographic factors associated with high-risk HPV infection in UK women. British journal of cancer 97:133-139.

Cuzick J, Clavel C, Petry KU, Meijer CJ, Hoyer H, Ratnam S, Szarewski A, Birembaut P, Kulasingam S, Sasieni P, Iftner T. 2006. Overview of the European and North 
American studies on HPV testing in primary cervical cancer screening. International journal of cancer 119:1095-1101.

Cuzick J, Szarewski A, Cubie H, Hulman G, Kitchener H, Luesley D, McGoogan E, Menon U, Terry G, Edwards R, Brooks C, Desai M, Gie C, Ho L, Jacobs I, Pickles C, Sasieni P. 2003. Management of women who test positive for high-risk types of human papillomavirus: the HART study. Lancet 362:1871-1876.

Dalstein V, Riethmuller D, Pretet JL, Le Bail Carval K, Sautiere JL, Carbillet JP, Kantelip B, Schaal JP, Mougin C. 2003. Persistence and load of high-risk HPV are predictors for development of high-grade cervical lesions: a longitudinal French cohort study. International journal of cancer 106:396-403.

Franco EL, Villa LL, Sobrinho JP, Prado JM, Rousseau MC, Desy M, Rohan TE. 1999. Epidemiology of acquisition and clearance of cervical human papillomavirus infection in women from a high-risk area for cervical cancer. The Journal of infectious diseases 180:1415-1423.

Gravitt PE, Kovacic MB, Herrero R, Schiffman M, Bratti C, Hildesheim A, Morales J, Alfaro M, Sherman ME, Wacholder S, Rodriguez AC, Burk RD. 2007. High load for most high risk human papillomavirus genotypes is associated with prevalent cervical cancer precursors but only HPV16 load predicts the development of incident disease. International journal of cancer 121:2787-2793.

Ho GY, Bierman R, Beardsley L, Chang CJ, Burk RD. 1998. Natural history of cervicovaginal papillomavirus infection in young women. The New England journal of medicine 338:423-428.

Jacobs MV, Walboomers JM, Snijders PJ, Voorhorst FJ, Verheijen RH, Fransen-Daalmeijer N, Meijer CJ. 2000. Distribution of 37 mucosotropic HPV types in women with 
cytologically normal cervical smears: the age-related patterns for high-risk and lowrisk types. International journal of cancer 87:221-227.

Khan MJ, Castle PE, Lorincz AT, Wacholder S, Sherman M, Scott DR, Rush BB, Glass AG, Schiffman M. 2005. The elevated 10-year risk of cervical precancer and cancer in women with human papillomavirus (HPV) type 16 or 18 and the possible utility of type-specific HPV testing in clinical practice. Journal of the National Cancer Institute 97:1072-1079.

Koliopoulos G, Arbyn M, Martin-Hirsch P, Kyrgiou M, Prendiville W, Paraskevaidis E. 2007. Diagnostic accuracy of human papillomavirus testing in primary cervical screening: a systematic review and meta-analysis of non-randomized studies. Gynecologic oncology 104:232-246.

Kyrgiou M, Koliopoulos G, Martin-Hirsch P, Arbyn M, Prendiville W, Paraskevaidis E. 2006. Obstetric outcomes after conservative treatment for intraepithelial or early invasive cervical lesions: systematic review and meta-analysis. Lancet 367:489-498.

Lai CH, Chao A, Chang CJ, Chao FY, Huang HJ, Hsueh S, Lin CT, Cheng HH, Huang CC, Yang JE, Wu TI, Chou HH, Chang TC. 2008. Host and viral factors in relation to clearance of human papillomavirus infection: a cohort study in Taiwan. International journal of cancer 123:1685-1692.

Mayrand MH, Duarte-Franco E, Rodrigues I, Walter SD, Hanley J, Ferenczy A, Ratnam S, Coutlee F, Franco EL. 2007. Human papillomavirus DNA versus Papanicolaou screening tests for cervical cancer. The New England journal of medicine 357:15791588.

Moberg M, Gustavsson I, Gyllensten U. 2004. Type-specific associations of human papillomavirus load with risk of developing cervical carcinoma in situ. International journal of cancer 112:854-859. 
Moberg M, Gustavsson I, Wilander E, Gyllensten U. 2005. High viral loads of human

2

3 papillomavirus predict risk of invasive cervical carcinoma. British journal of cancer 92:891-894.

Munoz N, Hernandez-Suarez G, Mendez F, Molano M, Posso H, Moreno V, Murillo R, Ronderos M, Meijer C, Munoz A. 2009. Persistence of HPV infection and risk of high-grade cervical intraepithelial neoplasia in a cohort of Colombian women. British journal of cancer 100:1184-1190.

Nobbenhuis MA, Walboomers JM, Helmerhorst TJ, Rozendaal L, Remmink AJ, Risse EK, van der Linden HC, Voorhorst FJ, Kenemans P, Meijer CJ. 1999. Relation of human papillomavirus status to cervical lesions and consequences for cervical-cancer screening: a prospective study. Lancet 354:20-25.

Paavonen J, Naud P, Salmerón J, Wheeler CM, Chow SN, Apter D, Kitchener H, Castellsague X, Teixeira JC, Skinner SR, Hedrick J, Jaisamrarn U, Limson G, Garland S, Szarewski A, Romanowski B, Aoki FY, Schwarz TF, Poppe WA, Bosch FX, Jenkins D, Hardt K, Zahaf T, Descamps D, Struyf F, Lehtinen M, Dubin G; HPV PATRICIA Study Group, Greenacre M. 2009. Efficacy of human papillomavirus (HPV)-16/18 AS04-adjuvanted vaccine against cervical infection and precancer caused by oncogenic HPV types (PATRICIA): final analysis of a double-blind, randomised study in young women. Lancet 374(9686):301-14

Pretet JL, Jacquard AC, Carcopino X, Charlot JF, Bouhour D, Kantelip B, Soubeyrand B, Leocmach Y, Mougin C, Riethmuller D. 2007. Human papillomavirus (HPV) genotype distribution in invasive cervical cancers in France: EDITH study. International journal of cancer 122:428-32.

Ralston Howe E, Li Z, McGlennen RC, Hellerstedt WL, Downs LS, Jr. 2009. Type-specific prevalence and persistence of human papillomavirus in women in the United States 
who are referred for typing as a component of cervical cancer screening. American journal of obstetrics and gynecology 200:245 e241-247.

Sankaranarayanan R, Nene BM, Shastri SS, Jayant K, Muwonge R, Budukh AM, Hingmire S, Malvi SG, Thorat R, Kothari A, Chinoy R, Kelkar R, Kane S, Desai S, Keskar VR, Rajeshwarkar R, Panse N, Dinshaw KA. 2009. HPV screening for cervical cancer in rural India. The New England journal of medicine 360:1385-1394.

Saunier M, Monnier-Benoit S, Mauny F, Dalstein V, Briolat J, Riethmuller D, Kantelip B, Schwarz E, Mougin C, Pretet JL. 2008. Analysis of human papillomavirus type 16 (HPV16) DNA load and physical state for identification of HPV16-infected women with high-grade lesions or cervical carcinoma. Journal of clinical microbiology 46:3678-3685.

Schlecht NF, Kulaga S, Robitaille J, Ferreira S, Santos M, Miyamura RA, Duarte-Franco E, Rohan TE, Ferenczy A, Villa LL, Franco EL. 2001. Persistent human papillomavirus infection as a predictor of cervical intraepithelial neoplasia. JAMA 286:3106-3114.

Tamalet C, Richet H, Carcopino X, Henry M, Leretraite L, Heid P, Leandri FX, SanchoGarnier H, Piana L. 2010. Testing for Human Papillomavirus and measurement of viral load of HPV 16 and 18 in self-collected vaginal swabs of women who do not undergo cervical cytological screening in southern France. Journal of medical virology 82:1431-1437.

van Duin M, Snijders PJ, Schrijnemakers HF, Voorhorst FJ, Rozendaal L, Nobbenhuis MA, van den Brule AJ, Verheijen RH, Helmerhorst TJ, Meijer CJ. 2002. Human papillomavirus 16 load in normal and abnormal cervical scrapes: an indicator of CIN II/III and viral clearance. International journal of cancer 98:590-595. 
1 Winer RL, Feng Q, Hughes JP, O'Reilly S, Kiviat NB, Koutsky LA. 2008. Risk of female human papillomavirus acquisition associated with first male sex partner. The Journal of infectious diseases 197:279-282.

4 Winer RL, Hughes JP, Feng Q, O'Reilly S, Kiviat NB, Holmes KK, Koutsky LA. 2006. 5 Condom use and the risk of genital human papillomavirus infection in young women. The New England journal of medicine 354:2645-2654.

7 Wise J. 2009. Age for starting cervical cancer screening in England will not be lowered. BMJ 8 338:b2583.

9 Woodman CB, Collins S, Winter H, Bailey A, Ellis J, Prior P, Yates M, Rollason TP, Young 10 LS. 2001. Natural history of cervical human papillomavirus infection in young women: a longitudinal cohort study. Lancet 357:1831-1836. 